\title{
Significance of Sowing Dates and Meteorological Parameters on Severity of Stem Gall of Coriander Caused by Protomyces
} macrosporus

\begin{abstract}
Background: Coriander (Coriandrum sativum L.) belongs to family Apiaceae is generally grown in winter season as a main crop in India. Stem gall of coriander caused by Protomyces macrosporus L. is a serious disease damaging all aerial plant parts. Under favourable ecological conditions, the disease may lead losses to the extent of 100 per cent therefore it is necessary to investigate the epidemiology of the disease to devise suitable remedial measures

Methods: The field experiment was conducted during Kharif season of 2018 with two varieties to study the effect of different meteorological parameters on stem gall of coriander at different sowing dates (1 $1^{\text {st }}$ week of November to $1^{\text {st }}$ week of December). The stem gall severity was recorded at weekly intervals from the start of its incidence.

Result: The disease severity was lowest $(5.42 \%)$ in the variety DH-36 sown in $3^{\text {rd }}$ week of November and maximum disease severity $(11.88 \%)$ was observed in variety $\mathrm{DH}-228$ sown in $1^{\text {st }}$ week of December. The quantitative relationship between the disease severity and weather variables at different dates of sowing for two varieties was obtained by performing correlation analysis. The temperature (maximum and minimum) and sunshine hours had positive correlation with per cent disease intensity, while relative humidity (morning and evening) and remaining weather parameters were non-significant at each dates of sowing but correlated with the disease intensity.
\end{abstract}

Key words: Coriander, Meteorological parameters, Protomyces macrosporus, Stem gall.

\section{INTRODUCTION}

Spices play an important role not only as condiments but in the Indian agricultural economy owing to medicinal, industrial and processing point of view. India is known as "Home of Spices" and its spices are considered to be best in quality in the world. Coriander (Coriandrum sativum L.) an annual herbaceous plant $(2 n=22)$, belongs to family Apiaceae is generally grown in winter season as a main crop in India (Singh and Verma, 2015).

In India coriander is grown mainly in Rajasthan, Madhya Pradesh, Assam, Gujarat, Andhra Pradesh, Odisha, Uttar Pradesh and Haryana (Leharwan and Gupta 2019). India occupies an area of 664 thousand ha with production of 861 thousand MT and productivity 1.3 MT per ha. In Haryana it is cultivated in 2400 ha with production of 4400 MT and productivity 1.83 MT per ha (Anonymous, 2018).

Coriander crop is prone to various fungal diseases viz., powdery mildew, wilt and stem gall. Stem gall caused by Protomyces macrosporus $\mathrm{L}$. is a serious disease of coriander damaging to all the aerial plant parts (Verma et al. 2019). In India, stem gall of coriander was first reported by Sydow and Butler (1911) from Bihar and later on by Gupta (1954) in other states.

The gall appears in the form of tumor like swellings on stems, leaves, peduncles and also deformed seeds, causing loss in yield as well as quality. Lakra (1999) reported about $16.1-55 \%$ seed loss due to stem gall under field conditions. Malhotra et al. (2016) observed that presence of excess
Department of Plant Pathology, College of Agriculture, Chaudhary Charan Singh Haryana Agricultural University,

Hisar-125 004, Haryana, India.

Corresponding Author: Kushal Raj, Department of Plant Pathology, College of Agriculture, Chaudhary Charan Singh Haryana Agricultural University, Hisar-125 004, Haryana, India. Email: kushalraj@hau.ac.in

How to cite this article: Vijaykumar, S., Raj, K., Soni, N. (2021). Significance of Sowing Dates and Meteorological Parameters on Severity of Stem Gall of Coriander Caused by Protomyces macrosporus. Indian Journal of Agricultural Research. DOI: 10.18805/ IJARe.A-5841.

Submitted: 04-06-2021 Accepted: 06-10-2021 Online: 16-11-2021

soil moisture, low sunshine hours due to cloudy weather in winter season ameliorate the spread of stem gall and damages the crop to the extent of 100 per cent.

Among various factors, weather conditions play a predominant role in determining the course and severity of epidemics, however, information on this aspect for stem gall disease is limited. Stem gall is dreadful disease and difficult to manage by one component, therefore it needs thorough understanding of epidemiology for better disease management. The present investigation was carried out to study the effect of weather variables on stem gall of coriander at different sowing date to explore various remedial measures. 


\section{MATERIALS AND METHOdS Effect of sowing time}

Two coriander cultivars, one for seed purpose (DH-36) and one for leafy vegetable purpose (DH-228) were sown under natural conditions in Plant Pathology experimental area of CCS HAU Hisar, in randomized block design with three replications on five dates viz., $1^{\text {st }}$ week November, $2^{\text {nd }}$ week November, $3^{\text {rd }}$ week November, $4^{\text {th }}$ week November and $1^{\text {st }}$ week December during year 2018. The size of the plot was $4 \times 2.4 \mathrm{~m}^{2}$ with row to row distance of $30 \mathrm{~cm}$ and plant to plant distance of $20 \mathrm{~cm}$. Recommended dose of fertilizers were applied $(\mathrm{N}=25 \mathrm{~kg} /$ acre and $\mathrm{P}=25 \mathrm{~kg} /$ acre $)$ and along with other cultural practices optimum crop growth. Observations on disease severity were recorded at weekly interval as per the 0-4 scale Lakra, (1999).

\section{Epidemiology of the disease}

The role of environmental factors (temperature, relative humidity, rainfall and sunshine hours) on the progress of stem gall disease on two coriander varieties (DH-36 and $\mathrm{DH}-228)$ sown at different dates was studied. The data on the disease progress was recorded at weekly intervals starting from disease appearance. The disease severity was calculated by using 0-4 scale (Table 1 ) at weekly intervals up to the crop maturity (Kumar et al., 2016).

The disease severity (\%) was calculated by using formula given by McKinney (1923).

Disease severity $(\%)=$

Sum of all disease ratings

Total no. of disease rating $\times$ Maximum disease grade

\section{Calculation of apparent infection rate ( $r$ )}

The apparent infection rate (unit per week) of the disease for two varieties was calculated by using the formula given by Vanderplank (1963) as mentioned below:

$$
r=\frac{2.3}{\left(t_{2}-t_{1}\right)}\left\{\log _{e} \frac{x_{2}}{1-x_{2}}-\log _{e} \frac{x_{1}}{1-x_{1}}\right\}
$$

Where,

$r=$ Apparent rate of infection at log phase of epidemic development.

$t_{1}$ and $t_{2}$ is time intervals when disease severities are $x_{1}$ and $\mathrm{x}_{2}$ respectively.

Table 1: Severity scale of stem gall of coriander.

\begin{tabular}{lc}
\hline Plant part & Score or rating \\
\hline Stem & 30 points \\
Seed & 20 points \\
Leaves & 20 points \\
Pedicel & 30 points \\
Total & 100 points \\
\hline
\end{tabular}

The score of each unit depends on the amount of the disease (on the length for stems and pedicels, area covered for leaves and for seeds number of infected seed).
Accordingly, the data pertaining to above parameters were recorded to calculate the apparent infection rate $(r)$.

\section{Calculation of area under disease progress curve (AUDPC)}

The area under disease progress curve was calculated for the cultivars by using the formula given by Vanderplank (1963).

$$
\text { AUDPC }=\sum_{i=1}^{k}\left(y_{i}+y_{i+1}\right)+\left(t_{i+1}-t_{i}\right)
$$

Where

$\mathrm{k}=$ Number of successive evaluation

$y_{i}=$ Disease severity at time $t_{i}$

$y_{i+1}=$ Disease severity at time $t_{i+1}$

$t_{i}=$ Time when disease severity was $y_{i}$

$t_{i+1}=$ Time when disease severity was $y_{i+1}$

Accordingly, the data relating to above parameters was recorded to calculate the AUDPC.

\section{RESULTS AND DISCUSSION}

Weather conditions play a predominant role in determining the progress and severity of disease. In present investigations, the progression and intensity of stem gall of coriander was observed on two different varieties sown on five different dates during Rabi 2018-2019. The data presented in Table 2 indicates that the severity of stem gall of coriander was influenced with sowing dates. The stem gall of coriander appeared during first week of March 2019 in both varieties (DH-228 and $\mathrm{DH}-36)$ sown on five different dates (Table 2). The temperature during this period was $24.2^{\circ} \mathrm{C}$ (maximum) and $8.0^{\circ} \mathrm{C}$ (minimum), while relative humidity $(\mathrm{RH})$ was $93.0 \%$ (morning) and $53 \%$ (evening) and sunshine hours and rainfall was 5.8 and $14.8 \mathrm{~mm}$, respectively. There was significant difference in disease severity between two varieties over different sowing dates. The disease severity was lowest $(5.42 \%)$ in variety $\mathrm{DH}-36$ sown during $3^{\text {rd }}$ week of November and maximum in $\mathrm{DH}$ $228(11.88 \%)$ sown in $1^{\text {st }}$ week of December (Table 3$)$. The results are similar to the observation of Tripathi (2003) who reported that early and late sowing of coriander exhibited less mean disease severity as compared to other dates and crop sown on 16 November showed comparatively low intensity of stem gall (11\%). Verma et al. (2017) also reported best time sowing of coriander between 30 October - 15 November.

The quantitative relationship between the disease severity and weather variables for different dates of sowing for two varieties was obtained by performing correlation analysis. Significant positive correlation was observed with temperature when sown during $3^{\text {rd }}$ week, $4^{\text {th }}$ week of November and $1^{\text {st }}$ week of December and effect of temperature was non-significant in crop sown during $1^{\text {st }}$ and $2^{\text {nd }}$ week of November in variety of DH-228 (Table 4). The significant positive correlation was observed with temperature on each sowing date of variety $\mathrm{DH}-36$. The morning relative humidity and evening relative humidity both had negative correlation with both the varieties and other 
weather parameters had non-significant correlation with each date of sowing but correlated with the disease intensity. Similarly, Saxena et al. (2002) observed that minimum / maximum atmospheric temperature and relative humidity play an important role in the development of stem gall. The disease appeared when the minimum and maximum temperatures were 13.2 and $30.9^{\circ} \mathrm{C}$, respectively with relative humidity of 57.2 per cent however maximum disease intensity was recorded in the plants sown when the minimum and maximum temperature was 8.1 and $22.6^{\circ} \mathrm{C}$, respectively with relative humidity of 65.8 per cent.

Tripathi et al. (2003) reported that the relationship of disease severity with minimum temperature was negative and highly significant in early sown crop whereas maximum temperature exhibited negative and significant correlation with early as well as late sown crop. The relative humidity showed significant positive association with the disease intensity revealing that disease intensity increased with corresponding increase in relative humidity. Rainfall had positive but non-significant correlation with disease intensity in various dates of sowing. Malhotra et al. (2016) observed that the presence of excess moisture, low sunshine hours due to cloudy weather in winter season promote the spread of stem gall and damages the crop. Gupta et al. (2019) reported that very low and high temperature was also not favourable for development of stem gall of coriander.

\section{Area under disease progress curve (AUDPC)}

The disease progression over a period was also computed by AUDPC as exhibited in Fig 1. Based on the disease

Table 2: Progression of stem gall of coriander on two varieties sown on five different dates.

\begin{tabular}{|c|c|c|c|c|c|c|c|c|c|c|}
\hline \multirow{5}{*}{$\begin{array}{l}\text { Dates of } \\
\text { observations }\end{array}$} & \multicolumn{10}{|c|}{ Disease Intensity (\%) } \\
\hline & \multicolumn{5}{|c|}{ Variety $\mathrm{DH}-228$} & \multicolumn{5}{|c|}{ Variety $\mathrm{DH}-36$} \\
\hline & $1^{\text {st }}$ & $2^{\text {nd }}$ & $3^{\text {rd }}$ & $4^{\text {th }}$ & $1^{\text {st }}$ & $1^{\text {st }}$ & $2^{\text {nd }}$ & $3^{\text {rd }}$ & $4^{\text {th }}$ & $1^{\text {st }}$ \\
\hline & week & week & week & week & week & week & week & week & week & week \\
\hline & Nov & Nov & Nov & Nov & $\mathrm{Dec}$ & Nov & Nov & Nov & Nov & Dec \\
\hline 08-03-2019 & 6.67 & 5.83 & 3.33 & 6.67 & 8.33 & 4.17 & 3.33 & 2.50 & 5.83 & 8.33 \\
\hline 15-03-2019 & 10.00 & 8.33 & 6.67 & 10.00 & 10.00 & 5.83 & 5.00 & 4.17 & 8.33 & 9.17 \\
\hline 22-03-2019 & 10.83 & 10.00 & 8.33 & 12.50 & 14.00 & 8.33 & 6.67 & 5.83 & 9.17 & 12.50 \\
\hline 29-03-2019 & 11.67 & 10.83 & 10.00 & 15.00 & 15.17 & 11.67 & 10.83 & 9.17 & 13.33 & 16.67 \\
\hline
\end{tabular}

Table 3: Effect of different dates of sowing on severity of stem gall of coriander and area under disease progress curve (AUDPC).

\begin{tabular}{lcccc}
\hline \multirow{2}{*}{ Date of sowing } & \multicolumn{2}{c}{ Disease severity (\%) } & AUDPC \\
\cline { 2 - 5 } & DH-228 & DH-36 & DH-228 & 210.00 \\
\hline $1^{\text {st }}$ week of November & $9.79(3.27)$ & $7.50(2.87)$ & 186.67 & 154.58 \\
$2^{\text {nd }}$ week of November & $8.75(3.10)$ & $6.46(2.68)$ & 151.67 & 131.25 \\
$3^{\text {rd }}$ week of November & $7.08(2.80)$ & $5.42(2.48)$ & 233.33 & 110.83 \\
$4^{\text {th }}$ week of November & $11.04(3.44)$ & $9.17(3.16)$ & 250.26 & 189.58 \\
$1^{\text {st }}$ week of December & $11.88(3.54)$ & $11.67(3.53)$ & & 239.17 \\
CD at 5\% & $(0.180)$ & $(0.115)$ & \\
\hline
\end{tabular}

${ }^{*}$ Figurs in the parentheses are square root transformed values.

Table 4: Correlation matrix between weather parameters and per cent disease severity of stem gall in two coriander varieties at different dates of sowing.

\begin{tabular}{|c|c|c|c|c|c|c|c|c|c|c|}
\hline \multirow{3}{*}{ Weather variables } & \multicolumn{10}{|c|}{ Correlation } \\
\hline & \multicolumn{5}{|c|}{ DH-228 } & \multicolumn{5}{|c|}{$\mathrm{DH}-36$} \\
\hline & $\begin{array}{l}\text { Nov } 1^{\text {st }} \\
\text { week }\end{array}$ & $\begin{array}{l}\text { Nov } 2^{\text {nd }} \\
\text { week }\end{array}$ & $\begin{array}{c}\text { Nov } 3^{\text {rd }} \\
\text { week }\end{array}$ & $\begin{array}{c}\text { Nov } 4^{\text {th }} \\
\text { week }\end{array}$ & $\begin{array}{l}\text { Dec } 1^{\text {st }} \\
\text { week }\end{array}$ & $\begin{array}{l}\text { Nov } 1^{\text {st }} \\
\text { week }\end{array}$ & $\begin{array}{c}\text { Nov } 2^{\text {nd }} \\
\text { week }\end{array}$ & $\begin{array}{l}\text { Nov } 3^{\text {rd }} \\
\text { week }\end{array}$ & $\begin{array}{c}\text { Nov } 4^{\text {th }} \\
\text { week }\end{array}$ & $\begin{array}{c}\text { Dec } 1^{\text {st }} \\
\text { week }\end{array}$ \\
\hline Temperature maximum (X1) & 0.924 & 0.927 & $0.962^{*}$ & $0.971^{*}$ & $0.976^{*}$ & $0.968^{*}$ & $0.979^{*}$ & $0.983^{*}$ & $0.996^{* *}$ & $0.998^{*}$ \\
\hline Temperature minimum (X2) & 0.76 & 0.776 & 0.846 & 0.898 & 0.895 & $0.962^{*}$ & $0.984^{*}$ & $0.975^{*}$ & $0.972^{*}$ & $0.970^{*}$ \\
\hline Relative humidity morning (X3) & -0.741 & -0.729 & -0.789 & -0.806 & -0.803 & -0.851 & -0.903 & -0.893 & -0.931 & -0.837 \\
\hline Relative humidity evening (X4) & -0.808 & -0.762 & -0.751 & -0.692 & -0.887 & -0.604 & -0.647 & -0.657 & -0.735 & -0.53 \\
\hline Sunshine (X5) & 0.677 & 0.624 & 0.628 & 0.577 & 0.782 & 0.521 & 0.586 & 0.587 & 0.677 & 0.457 \\
\hline Pan evaporation (X6) & 0.847 & 0.844 & 0.893 & 0.909 & 0.881 & 0.934 & $0.963^{*}$ & $0.962^{*}$ & $0.985^{*}$ & 0.915 \\
\hline Rainfall (X7) & -0.948 & -0.927 & -0.882 & -0.818 & -0.948 & -0.673 & -0.653 & -0.683 & -0.716 & -0.591 \\
\hline
\end{tabular}

*Significance at CD 5\% ** Significance at CD 1\%. 


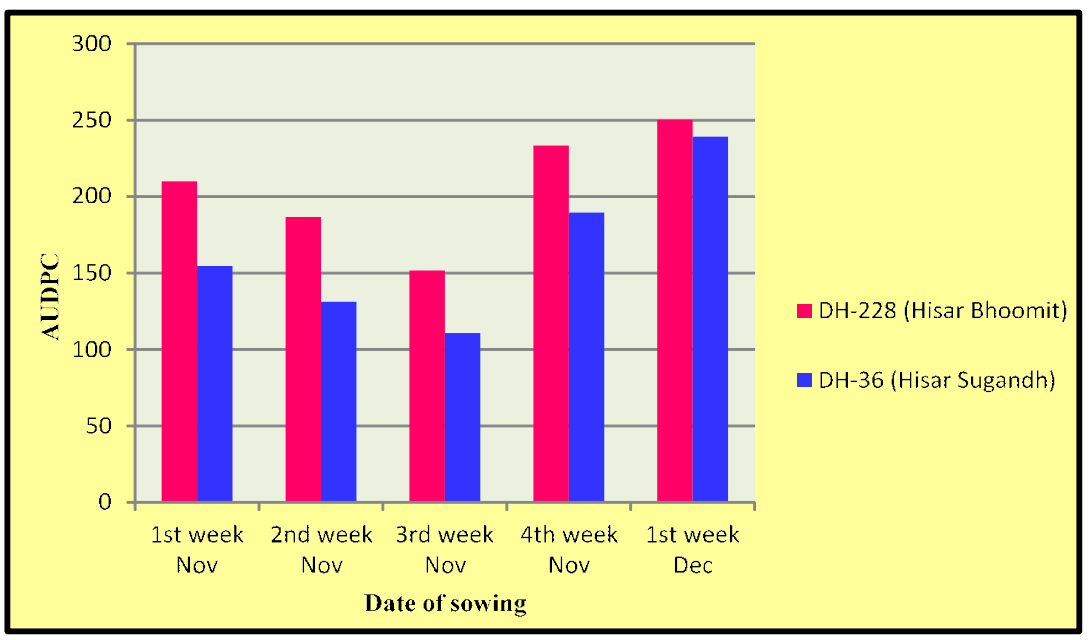

Fig 1: AUDPC of stem gall of coriander on two coriander varieties sown on five different dates.

Table 5: Effect of different sowing dates on apparent infection rate $(r)$ of stem gall of coriander.

\begin{tabular}{|c|c|c|c|c|c|c|c|c|}
\hline \multirow{5}{*}{$\begin{array}{l}\text { Dates of } \\
\text { sowing }\end{array}$} & \multicolumn{7}{|c|}{ Infection rate } & \\
\hline & \multicolumn{3}{|c|}{ Variety DH 228} & \multicolumn{5}{|c|}{ Variety $\mathrm{DH} 36$} \\
\hline & 8-03-19 & $16-03-19$ & 23-03-19 & & 8-03-19 & $16-03-19$ & 23-03-19 & \\
\hline & to & to & to & Mean & to & to & to & Mean \\
\hline & $15-03-19$ & 22-03-19 & 29-03-19 & & $15-03-19$ & 22-03-19 & 29-03-19 & \\
\hline $1^{\text {st }}$ week of November & 0.131 & 0.141 & 0.141 & 0.138 & 0.130 & 0.133 & 0.136 & 0.133 \\
\hline $2^{\text {nd }}$ week of November & 0.133 & 0.140 & 0.141 & 0.138 & 0.125 & 0.132 & 0.132 & 0.130 \\
\hline $3^{\text {rd }}$ week of November & 0.117 & 0.137 & 0.137 & 0.130 & 0.112 & 0.130 & 0.110 & 0.117 \\
\hline $4^{\text {th }}$ week of November & 0.134 & 0.139 & 0.142 & 0.138 & 0.133 & 0.140 & 0.137 & 0.137 \\
\hline $1^{\text {st }}$ week of December & 0.136 & 0.142 & 0.144 & 0.141 & 0.140 & 0.141 & 0.139 & 0.140 \\
\hline
\end{tabular}

progression at different intervals, AUDPC was statistically analyzed and it was found that the value of AUDPC was lowest in $3^{\text {rd }}$ week of November sown crop while it was maximum when crop was sown during $1^{\text {st }}$ week of December. It was observed that, AUDPC was lowest (110.83) in DH-36 which showed less disease intensity and maximum on variety $\mathrm{DH}-228$ (250.26). The AUDPC increased in both varieties when sown early as well as in case of late sown. The trend of AUDPC was more in the variety $\mathrm{DH}-228$ while DH-36 showed less AUDPC under all five dates of sowing.

\section{Apparent infection rate (r)}

The apparent infection rate was higher during March $16^{\text {th }}$ to March $22^{\text {nd }}$ on different dates of sowing however, it was less from $23^{\text {rd }}$ March to $29^{\text {th }}$ March in both the varieties at all dates of sowing (Table 5). The ' $r$ ' week ${ }^{-1}$ increased and reached its maximum at initial period of observation on five different dates of sowing.

\section{CONCLUSION}

The temperature (maximum and minimum) and sunshine hours had positive correlation with per cent disease intensity, while relative humidity (morning and evening) and remaining other weather parameters were non-significant at each dates of sowing and chances of stem gall development will be minimum if crop sown during $3^{\text {rd }}$ week of November.

\section{REFERENCES}

Gupta, J.S. (1954). Disease appraisal of stem gall of coriander. Indian Phytopathology. 7: 53-60.

Gupta, M., Leharwan, M. and Shukla, A. (2019). Effect of temperature and moisture levels on disease development of stem gall of coriander. Agriculture Science Digest: A Research. Journal. 38(4). DOI 10.18805/ag.D 4745.

Anonymous (2018). https://www.indiastat.com/table/agriculture/2/ coriander/19559/337538/data.aspx.

Kumar, G., Patel, J.S., Yadav, S.K., Kumar, A. and Saxena, R.P. (2016). Evaluation of coriander germplasm against stem gall disease of coriander (Coriandrum sativum L.). Journal of Pure and Applied Microbiology. 10(2): 1-6.

Lakra, B.S. (1999). Assessment of losses due to stem gall of coriander. Plant Disease Research. 14: 85-87.

Leharwan, M. and Gupta, M. (2019). Stem Gall of Coriander: A Review. Agricultural Reviews. 40(2): 121-128.

Malhotra, S.K., Kakani, R.K., Sharma, Y.K. and Singh, D.K. (2016). Ajmer coriander-1(NRCSS, ACR-1) resistant to stem gall disease- an innovative farming technology. Indian Journal Arecanut, Spices Medicinal Plants. 18: 1-7. 
Mckinney, H.H. (1923). Influence of soil temperature and moisture on infection of wheat seedling by Helminthosporium sativum. Journal of Agricultural Research. 26: 195-217.

Saxena, R.P., Dixit, S., Pandey, V.P. and Singh, V.K. (2002). Germplasm Screening for Stem Gall Disease in Coriander. In: National Symposium on Integrated Management of Plant Disease of mid-Eastern India with a Cropping System Perspective, Held at NDUAT, Faizabad during 5-7 December, 2002.

Singh, R.K. and Verma, S.S. (2015). Characterization of coriander (Coriandrum sativum) based on the morphological traits. Journal of Agricultural Research. 2: 221-224.

Sydow, H. and Butler, E.J. (1911). Fungi India Coriantalis. Annals of Mycolology. 9: 372-421

Tripathi, A.K. (2003). Effect of sowing dates and weather parameters on stem gall disease of coriander. Indian Phytopathology. 56: 191-193.
Tripathi, A.K., Chauhan, R.K.S., Bartaria. and Chauhan, S. (2003) Quantitative and qualitative loss in coriander due to Protomyces macrosporus. Indian Phytopathology. 56: 451-452.

Vanderplank, J.E. (1963). Plant Diseases, Epidemics and Control. Academic Press, New York, 249-259.

Verma, P., Meena, D.S., Jadon, C. and Singh, D.K. (2017). Effect of sowing time and management practices on incidence of stem gall and seed yield of coriander (Coriandrum sativum L.). International Journal of Seed Spices. 7(1): 79-81.

Verma, P., Yadav, M.L., Meena, C.B. and Yadav D.L. (2019). Stem gall disease of coriander: Causes and integrated management. International Journal of Current Microbiology and Applied Sciences. 8(11): 2573-2580. 